Article

\title{
Collaboration Vouchers: A Policy to Increase Population Wellbeing
}

\author{
Benjamin Heslop ${ }^{1, *}$, Antony Drew ${ }^{2}$, Elizabeth Stojanovski ${ }^{3}$ Kylie Bailey $^{1}$ (D) \\ and Jonathan Paul 1 (iD \\ 1 School of Medicine and Public Health, University of Newcastle, University Drive, Callaghan 2308, Australia; \\ kylie.bailey@newcastle.edu.au (K.B.); jonathan.paul@newcastle.edu.au (J.P.) \\ 2 School of Mathematical and Physical Sciences (Statistics), University of Newcastle, University Drive, \\ Callaghan 2308, Australia; antony.drew@newcastle.edu.au \\ 3 Newcastle Business School (International Business), University of Newcastle, University Drive, \\ Callaghan 2308, Australia; elizabeth.stojanovski@newcastle.edu.au \\ * Correspondence: benjamin.heslop@uon.edu.au
}

Received: 13 April 2018; Accepted: 28 May 2018; Published: 3 June 2018

\begin{abstract}
While economic liberalism has delivered national wealth, substantial portions of the population have been left behind. The precariously and unemployed experience reduced wellbeing that may be remedied by their greater involvement in egalitarian, purposive collaborative groups. Policy to achieve this objective may be assisted by an understanding of how positive psychology interacts with social psychology. The PILAR model of collaboration is postulated to translate between an individual's psychological capital (PsyCap) and their meeting of basic psychological needs (BPN). In a proposed cyclical model, a collaborating individual will meet BPN, thereby experience enhanced wellbeing, which bolsters PsyCap, and hence promotes further collaboration. Given collaboration is amenable to incentivisation, a policy of collaboration vouchers might cost-effectively promote individual wellbeing throughout society, whilst having complementary effects such as social cohesion.
\end{abstract}

Keywords: positive psychology; basic psychological needs; psychological capital; PILAR; collaboration; universal basic income; wellbeing

\section{Innovation versus Wellbeing}

Innovation is a process that intends to make a new product, service, or method available for wider use [1]. Businesses that innovate will better adapt to meet changing market demands as well as economic and technological conditions. Economies constituted by adaptable businesses therefore generate greater wealth than, for instance, command economies, or highly regulated business environments, which are slower to adapt [2]. While innovative, open-access nations [3] produce wealth that bolsters standard of living and general population wellbeing, benefits initially- and primarily-accrue to owners of capital and the professional classes [4,5].

Innovation within an organisation often requires a collaborative culture in which groups of employees explore new ideas [6,7]. For those making meaningful contributions to an organisation's collaboration and innovation, wellbeing is increased [8]. While an open-access economy generates wealth and wellbeing for full-time workers in collaborative organisations [9], precarious workers experience poor pay, insecure employment [10], and often a lack of meaningful collaboration $[4,11]$. Such economic divisions are represented by Chesbrough's [12] open innovation, which recommends treating workers as knowledge-bearing commodities to be utilised through freelance contracts. To offset the lack of collaboration that accompanies semiskilled workers, compounded by damage to 
wellbeing from the financial uncertainty of zero-hour or piecework contracts, we propose broadening discretionary access to meaningful collaboration and thereby increase population wellbeing.

Innovation and wellbeing do not easily coexist when an open innovation ethos encourages social disruption and depersonalisation, such as for young people entering the labour market [13] who experience the precarious nature of piece and contract work [14]. While flexible arrangements allow a company to alter its' workforce in response to market conditions, a lack of financial certainty increases employees' stress, which may unfortunately also reduce their willingness to collaborate $[15,16]$. In addition, workplace disruption resulting in loss of relationships increases feelings of isolation. As individuals' corporate knowledge becomes less valued within a new business structure, personal agency is reduced, and thereby so is confidence to create novelty [17]. As a result, those in disrupted or precarious employment are not only less likely to innovate but may also risk a reduction of their wellbeing from lack of collaborative engagement [18]. Compounding this scenario for the precarious worker is lower pay, requiring longer hours in multiple jobs [17] and therefore less discretionary time to spend with family and friends.. Even should discretionary time be available, poorly-remunerated employees may have insufficient funds to participate in social activities that might otherwise increase their wellbeing. At a societal level, poorly paid and precarious employment diminishes the network of relationships among agentic individuals that enables society to function smoothly, termed social capital [19].

A policy remedy for the insecurity of actual or potential job loss is increasing financial and other support for the unemployed. One example is the Danish model of flexicurity, which provides generous unemployment benefits as well as training and other services to assist in finding work [20]. Flexicurity was effective in maintaining Danish workforce participation during the Great Recession of 2008, yet it has not been adopted internationally due to a popular fear that welfare promotes laziness [21]. The cost of a weak welfare system may be lost innovation because employees are less willing to make suggestions that challenge the status quo because employers or managers may be offended [22]. Another cost of a weak welfare system may be poorly treated or badly managed workers less able to leave their current employment without first cementing an alternative position [23]. A strong welfare system could increase innovation due to the capacity of well-run organisations to more easily attract higher-performing employees, at the expense of poorly-run organisations whose demise is therefore accelerated. The economy is therefore benefited by less resource waste due to poorly-run organisations' failed attempts to innovate due to a lack of meaningful collaboration, and concomitant damage to their employees' wellbeing [24].

A recently-advocated policy that may remedy the problem of low pay and/or long hours precluding discretionary collaboration is a universal basic income (UBI). This policy provides a guaranteed income to all citizens, which can be supplemented by any work the individual performs. For example, a French UBI of $€ 1100$ per month, slightly above the poverty line of $€ 987$ [25], would cost $€ 871$ billion or 35\% of GDP [26]. However, such a low UBI may only further depress wages as employers take advantage of the increased value to the employee of any "top up" income. Additionally, there is potential for price inflation in goods with inelastic supply, specifically accommodation, private transport, and higher-quality food, that would over time return an increasing portion of the UBI into profit for capital owners [27].

An alternative means of addressing low pay may be to directly target individual wellbeing rather than income, which may avoid profit-taking and so be less expensive than a UBI. Such a policy might increase discretionary collaboration for those whose workplace is not collaborative, or who lack sufficiently well-remunerated employment. Implementing such a policy could draw upon the decades of exploration of a UBI, implementation of which has thus far has been confounded not only by its high cost but also difficulty of finding political allies. On the right side of politics, for instance, capital owners do not wish to pay the requisite tax burden of a UBI, while on the left, trade unions have difficulty countenancing nonworkers (colloquially, "surfers") receiving a guaranteed income [28].

An alternative form of UBI intended to address the fear of surfers is a universal participation income (UPI) that only applies to those making a meaningful contribution to society, including employment, 
but also voluntary work, artistic expression, and environmental activities [28]. While a UPI theoretically identifies surfers, it is impossible to police, since nearly any activity can be presented as contributory. Yet if the idea of contribution is constrained to be participation within collaboration, then reliable oversight may be possible.

Collaboration is commonly perceived to emerge from reactions and behaviour in social situations, which social psychology encapsulates [29]. Yet, wellbeing can also be understood through the emerging field of positive psychology [18]. Therefore, insights into wellbeing generated through collaboration may require parallel consideration of positive psychology and social psychology, the latter of which may be substantially encapsulated by the PILAR model of collaboration.

\section{PILAR Model of Collaboration}

While in-person collaboration is considered key to wellbeing, demonstrated by burgeoning youth mental illness accompanying the prevalence of smartphones [30], there is no widely accepted model of collaboration that can be considered truly representative [31]. We select the PILAR model of collaboration due to its encapsulation of a wide range of social psychology theory [32] as well as consistency with oganisational psychology [33]. PILAR considers that humans have an array of perceptions that guide their decision to engage in a group, to reduce their investment, or to withdraw entirely [34]. PILAR asserts that the typical collaborator decides whether to commit to or leave a group based upon five perceptions of collaboration, or Pillars (Table 1).

Table 1. Definition of each Pillar within the PILAR Model of Collaboration.

\begin{tabular}{ll}
\hline \multicolumn{1}{c}{ Pillar } & \multicolumn{1}{c}{ PILAR Perception (Pillar) Definition } \\
\hline prospects & $\begin{array}{l}\text { Your opinion of whether the group will succeed, and if so, whether you will receive } \\
\text { your anticipated share of that success }\end{array}$ \\
\hline \multirow{2}{*}{ involved } & $\begin{array}{l}\text { Your willingness to cooperate with colleagues, either providing or receiving } \\
\text { assistance in the form of knowledge and physical aid }\end{array}$ \\
\hline liked & $\begin{array}{l}\text { Your sense of popularity and security based upon your perception of colleagues' } \\
\text { warmth and affection towards you }\end{array}$ \\
\hline agency & $\begin{array}{l}\text { The permission you feel to suggest change to the group's norms, processes, task } \\
\text { allocation, and strategy }\end{array}$ \\
\hline respect & Your opinion of a colleagues' task-relevant competence and general trustworthiness \\
\hline
\end{tabular}

\subsection{Prospects}

The prospects Pillar is the likelihood of the collaboration achieving its goal and of the collaborating member subsequently receiving their share of the anticipated benefit, for instance, produce from a community garden. When the member feels that his or her group is likely to fail, low prospects are experienced as uneasiness and foreboding. Even when the group itself is performing well, if the member suspects his or her share is at risk, for instance, continuing the community garden analogy, a favourite crop has failed while others are abundant, then prospects are perceived as low [32]. Hence, while members presumably hope the group succeeds, their priority is their personal share of the collective benefit. Within an organisation, prospects is similar to constructs such as outcome performance, team potency, and team efficacy [33].

\subsection{Involved}

The involved Pillar encourages two members to cooperate in providing knowledge or physical assistance to complete a task. It is experienced by the member as an openness to and comfort working with a specific colleague, which at high levels is experienced as enthusiasm to participate [35]. Lack 
of the involved perception is experienced as general trepidation and unease due to the potential risk of cooperation, such as embarrassment at needing help, an unappreciative recipient of advice, or their becoming a competitor for expert status [36]. Involved is postulated to be like constructs from organisational psychology such as contextual performance, mutual aid, task conflict, and internal communication [33].

\subsection{Liked}

The liked Pillar is associated with belonging and security, whereas being disliked leads to feelings of social isolation and insecurity. Those who perceive they are poorly liked may reduce the unpleasant feeling by mending relationships, or if this is not practical or desired, leaving the group entirely. This behaviour is prominent for those who hold an identity linked to their group, who therefore cannot tolerate being disliked by in-group colleagues, and willingly engage in out-group exclusion [37]. Liked within organisations is considered like constructs such as social cohesion, interpersonal climate, and in the negative sense, relationship conflict [33].

\subsection{Agency}

The agency Pillar describes feeling empowered to suggest change to the collaboration, for example, a strategy change based upon unforeseen dangers [38] or adjusting task responsibilities to member availability. Suggesting change usually challenges group norms and therefore others' expectations, which is personally risky [39], especially if the change is implemented but eventually fails. From an organisational psychology perspective, agency is similar to adaptability, process conflict, team goals, and psychological safety [33].

\subsection{Respect}

The respect Pillar reflects the member's perception of a colleague's competence and character [40]. High respect is faith and trust in colleagues' dependability, compared to low respect, which is associated with distrust and vigilance [41]. Within organisations, respect impacts upon task performance, team effectiveness, team transactive memory, and when others' respect for oneself is considered, also self-efficacy [33]. Having introduced the five Pillars, we investigate their consistency with positive psychology.

\subsection{PILAR and Innovation}

We consider how perceptions of each Pillar might affect employees ability to innovate, first over the initial invention phase, followed by commercialisation [1]. Before a member's idea is introduced to the group, they must calculate whether colleagues have sufficient collective efficacy or accumulated individualised respect to execute [42]. If so, the idea is pitched via agency, since execution of the innovation will necessitate changes to the group's strategy, task allocation, and resource utilisation. Whether the idea is taken up depends initially upon the group's consensus estimation of collective efficacy and whether they have the necessary skills and mutual trust. Enabling prospects to be assessed, members assess the group's collective efficacy in the context of external factors, such as prevailing competition or management resistance in the case of intrapreneurship that innovates within an organisation [43].

After the idea has been approved for commercial production, liked and involved are beneficial for maintaining productive relationships amidst complex decision-making and trade-offs enabling execution of the innovation [44]. For this reason, venture capitalists preferentially invest in teams that already have tested the market with a prototype and that demonstrate cohesion and cooperation [45]. Respect is also critical given the diverse mix of skills required, such as marketing, accountancy, and management, that must be present within a start-up or intrapreneurship team, often consisting of four or fewer members [46]. 


\section{Integrating Positive Psychology with PILAR}

The interaction between collaboration, innovation, and wellbeing is postulated to rely upon a three-stage process. First, that mentally well, effective collaborators typically possess psychological capital, or PsyCap [47]. Second, once collaboration is functioning and able to deliver innovative outcomes, members are rewarded by having their basic psychological needs (BPN) met [48]. Third, meeting (or exceeding) the member's BPN expectations replenishes (or increases) their PsyCap, which invigorates them for their next collaborative encounter [47]. These conceptions of collaborators possessing PsyCap resources, enabling them to meet BPN, which then to replenish PsyCap, is common in or at least implied by positive psychology literature $[49,50]$. The novelty of this article is proposing five separate channels within collaboration, each containing a two-stage process, that are the intervening mechanisms. We now define the components of PsyCap and BPN, which, for brevity, employ the taxonomic BPN component and PsyCap component.

\subsection{Components of Basic Psychological Needs (BPN)}

Self-determination theory (SDT) is the standard that any potential contender for a BPN must meet [51,52]. Specifically, SDT specifies that a BPN should generate in the person wellbeing, internalisation, and psychological growth [53]. Wellbeing is contentment and eudemonia, internalisation is identification with a moral framework, and psychological growth improves one's intrinsic motivation [53].

Autonomy, competence, and relatedness are the only BPN formally deemed to meet SDT's standards. BPN autonomy is a psychological need for personal choice, which in group situations, allows complying with the wishes of others when there is the option to refuse [53]. BPN autonomy is easier to achieve within a flat hierarchy, where compliance cannot be forced. BPN competence is a psychological need to manipulate one's environment under challenging conditions, which delivers a sense of mastery and skill. BPN relatedness is a psychological need to feel connected to others; that is, to care and be cared for. Effective collaboration will deliver all three BPN to its members.

\subsection{Components of Psychological Capital}

PsyCap resources accumulate and dissipate over time and are therefore considered to be statelike, halfway between fixed personality traits and variable moods and emotions [47]. We note that resemblances between PsyCaps are due to psychological capital being a conglomerate of numerous author's work. Luthans [54] originally proposed that PsyCap is constituted by four resources: hope, optimism, efficacy, and resilience. Luthans, Youssef, and Avolio [47] later proposed supplementary PsyCaps related to wisdom, such as gratitude, forgiveness, spirituality, courage, and emotional intelligence (EI). For this article, PsyCap-EI is selected as the fifth resource, defined as the ability to manage one's emotions and perceive emotions in others [55].

We have chosen EI because it is fundamental to collaboration, such that acquiring EI has long-lasting benefits. For example, a meta-analysis of research that taught EI to children has shown positive effects up to 18 years post-intervention, such as improved high school graduation rate and lower sexual risk-taking [56]. More specific to collaboration, Pradhan, Jena, Bhattacharya, and Nisar [57] demonstrated that EI promotes organisational citizenship behaviour (OCB), effectively ad hoc collaboration, for example, by informally assisting colleagues [58].

PsyCap-hope is the capacity to act in a fashion likely to succeed, which Snyder [59] determined has two components, willpower and pathways. Willpower is the member's ability to start work on a goal and then pursue it to completion. Pathways is the capacity to change direction when the current approach is blocked or becomes overly costly [59].

PsyCap-optimism is the capacity to perceive undesirable events as fleeting but desirable events as persistent and may be taken from two perspectives. One is an attribution perspective, where optimists expect good things to happen, whereas pessimists expect bad things will happen. This is rationalised as positive outcomes having enduring, global causes, whereas negative outcomes are 
temporary and localised [60]. For example, an attribution-based optimist might perceive social poverty as reducible, rather than inescapable. The second expectancy perspective is founded in the assumption that hard work will be rewarded [61]. Faced with misfortune, expectancy-based optimists will respond constructively to failure simply because they believe their efforts will be fruitful.

PsyCap-self-efficacy is a perceived capacity to successfully achieve intended outcomes, which is more targeted than the general "reward" of expectancy-based optimism [62]. Those with self-efficacy attribute any failure to insufficient effort in the past and will therefore expend greater effort in future. Those who regard themselves as inefficacious attribute their failures to low ability, and so upon failure, cease trying [63]. Rather than try, inefficaciousness individuals may prefer to deceptively embellish their personal reputation, for instance, through ego preservation (preventing formation of negative impressions by others) and impression management (conveying positive impressions to others) [64,65].

PsyCap-resilience is the ability to recover from adverse events and is increased by assets but decreased by risk factors. Assets are forces or influences external to oneself that assist in recovery, while risks are forces or influences that detract from recovery [66]. Improving the member's PsyCap-resilience requires increasing assets and decreasing risks, however, the three previous PsyCaps may also assist as "internal assets" [67]. The following section explains the two-step process by which each PsyCap translates, via a Pillar, to a BPN.

\subsection{Wellbeing as Antecedent to PsyCap}

Successful collaboration may foster the member's confidence in his or her personal approach to group situations, thus increasing PsyCap. Alternatively, failing to collaborate successfully, or at all, may reduce PsyCap, as demonstrated by the higher average PsyCap and wellbeing of employed versus unemployed. Achieving BPN is fundamentally rewarding for the member, and if those rewards are derived from collaboration, there may be greater likelihood of seeking future collaboration.

Cole [68] identified a cyclical relationship among PsyCap, wellbeing, and work, which we consider a result of employment providing increased opportunities for collaboration, both when present at the workplace and within personal time due to greater wealth and social status. We reinterpret Cole's cyclical model to maintain consistency with self-determination theory, given that satisfaction of BPN via collaboration generates wellbeing [69], leading to increased PsyCap and further collaboration [70], while acknowledging that the antecedents to PsyCap are not well-studied [71]. The member's increased PsyCap then promotes viable collaboration, which initiates the cycle again (Figure 1).

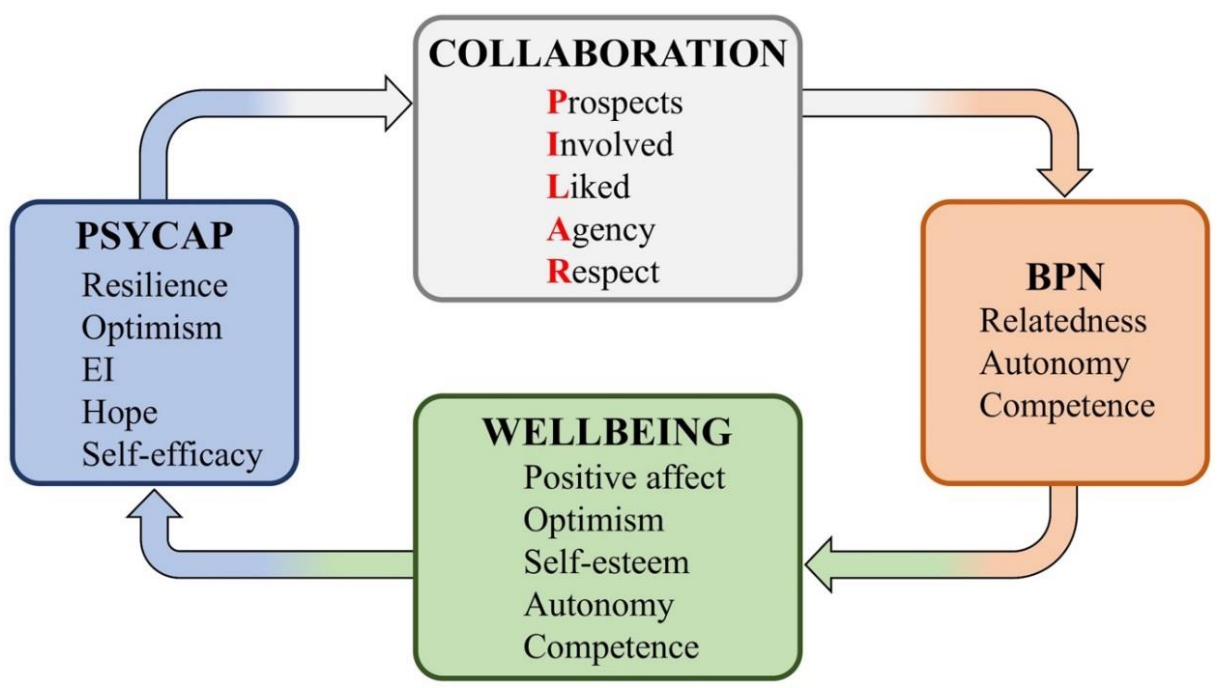

Figure 1. Cyclical interaction of collaboration, positive psychology, and wellbeing. 
Just as there is no accepted model of collaboration, there is also no accepted definition of wellbeing nor an associated survey instrument. Hone, Jarden, Schofield, and Duncan [72] nominated four wellbeing instruments (see Table 2 below) that, when considered in conjunction, demonstrate substantial overlap with PILAR and positive psychology. The overlap is extended by inclusion of the initial condition assumed by PILAR, termed idealised collaboration [32].

For PILAR to be applicable, the collaboration must consist of voluntarily participating members who possess a sincere desire to pursue the collective outcome. There also must initially be zero power distance between members, meaning in practice that members can only influence their colleagues through persuasion.

One common aspect of all four wellbeing instruments is engagement, which in a workplace context is one's motivation to complete and to immerse oneself in tasks [73]. PILAR asserts that members who perceive Pillars as high are more likely to remain engaged in collaboration or to even increase their investment. Conversely, if a member experiences lower Pillars, they may progressively disengage until leaving the group altogether. This is consistent with selfish engagement, which is a mechanism postulated to regulate group viability through members' accrued engagement decisions [74]. Specifically, selfish engagement contends that members instinctively regulate their engagement based on the group's likely benefit to them personally. For example, predicting that enough members will independently disengage from a group containing a cheater for the group to collapse. This indirect, collective punishment of a cheater may be more realistic than any single member assuming the cost of direct punishment, otherwise predicted by strong reciprocity [75].

Societal contribution is satisfaction from making a constructive contribution to society and is an element of two of the four instruments (Table 2). Societal contribution is implied by SDT's internalisation yet is not explicitly consistent with any BPN nor PsyCap. Societal contribution is also excluded from PILAR since any instance of collaboration can potentially achieve a socially detrimental outcome (for instance, importing narcotics). The remaining wellbeing elements common to two or more instruments are listed in Table 2. Autonomy is also included in Table 2 for later discussion.

Table 2. Wellbeing elements antecedent to PsyCap.

\begin{tabular}{cccccc}
\hline $\begin{array}{c}\text { Wellbeing } \\
\text { Instrument }\end{array}$ & PsyCap-resilience & PsyCap-optimism & PsyCap-EI & PsyCap-hope & PsyCap-self-efficacy \\
\hline MHC-SF & Positive affect & - & Self-acceptance & Autonomy & - \\
\hline ESS & Positive emotion & Optimism & Self-esteem & - & Competence \\
\hline FS & - & Optimism & $\begin{array}{c}\text { Self-acceptance } \\
\text { and Self-esteem }\end{array}$ & - & Competence \\
\hline PERMA & Positive emotion & - & - & - & $\begin{array}{c}\text { Accomplishment/ } \\
\text { Competence }\end{array}$ \\
\hline $\begin{array}{l}\text { Table 2 is reproduced from Hone et al. [72] who categorises common elements of four wellbeing instruments. } \\
\text { MHC-SF: Mental Health Continuum Short Form [76], ESS: European Social Survey [77], FS: Flourishing Scale [78], } \\
\text { PERMA: Positive Relationships, Engagement, Meaning, Accomplishments [79]. }\end{array}$
\end{tabular}

Positive affect, or happiness, may result from feeling that one's life choices are bearing their intended fruit. The alternative is unhappiness and stress from anticipating future losses. For example, those afflicted with serious medical conditions (such as HIV, cancer, chronic pain, or diabetes) show that positive affect predicts resilience [80-83]. This supports a contention that, when in a group situation, positive affect in the face of poor prospects indicates greater resilience to cope with future stressors.

We consider that optimism as an element of wellbeing that is antecedent to PsyCap-optimism, and that furthermore, feeling competent and accomplished is antecedent to PsyCap-self-efficacy. It is, however, less obvious that self-esteem is antecedent to PsyCap-EI. Forms of self-esteem considered most beneficial to collaboration are those that are implicit or unconscious and therefore less prone to instability from external stimuli that generate conscious reflection [84]. By contrast, those who seek validation from external markers of success, included from their friendships, are termed to have 
contingent self-esteem. For instance, a source of contingent self-esteem particularly prevalent in East Asia is national face, in which one prefers people to show regard for one's nation [85].

More relevant to group situations is friendship contingent self-esteem (FCSE), often generated by insecure attachments during childhood [86]. Those with FCSE find that loss of friendships may lead to depressive symptoms and general self-esteem instability [87]. For this reason, we contend that EI may be a critical skill in coping with fluctuations in self-esteem due to reduction in relationship quality. Supporting this, an observational study of 1660 Spanish adolescents found that self-esteem and EI work in tandem to reduce suicidal ideation resulting from cyberbullying [88]. In the following section, we contend that the member's perceived decrease in the liked Pillar results in a deficiency in BPN-relatedness.

Autonomy features in only one of the four wellbeing instruments (Table 2), but in agreement with BPN-autonomy, we consider it worthy of consideration. For example, welfare programs that provide grocery vouchers rather than cash inherently reduce autonomy [89] yet, when implemented within Australian Indigenous populations, these programs failed to improve school attendance rate despite this being a primary aim [90]. ${ }^{1}$ Nevertheless, an observational study of 689 American and Singaporean college students found that BPN-autonomy and scores from the Ryff autonomy scale were least correlated to the Diener Flourishing Scale [78]. This may have been the result of college students from wealthy nations already possessing sufficient autonomy. Yet, other cross-cultural researchers have proposed that autonomy is less relevant in collectivist countries, many of which are poorer [77]. Perhaps autonomy is less desired by those ill-equipped to manage it, such as wealthy consumers who lack time to consider options [91], or US employees of the firm Zappos, who had their corporate hierarchy suddenly flattened [92]. However, for deprived communities whose members already have little financial or cultural capacity to make choices, loss of autonomy may be detrimental [93].

This paradigm is suggested in PILAR, which defines agency as the member's capacity to suggest change to the group. When change is mandated by leaders, collectivist workplaces change more effectively compared to individualist cultures, where subordinates expect their opinions to be considered [1]. Australian Indigenous communities are culturally collectivist yet must change in response to tumult, such as removal of children, addiction, suicide, incarceration, and a high sugar diet leading to ill health and early death [93]. For example, Indigenous leaders are inviting people to refuse humbugging from itinerants that prevail upon a relative's hospitality yet continue self-destructive behaviours in their new home [94]. When tradition becomes irrelevant or forgotten, a people under threat must innovate to survive, which may explain why a policy that reduces autonomy within a collectivist culture is damaging to individual wellbeing.

This concludes discussion of elements of wellbeing as antecedents to PsyCaps. The next section considers whether collaboration, as measured by member's perception of the five Pillars, provides a mechanism to translate PsyCaps to BPN. As will be demonstrated, numerous theorists consider that a person possessing a particular PsyCap is more likely to fulfil their respective BPN. First, however, we outline how the accuracy of one's perception of the five Pillars dictates the engagement of colleagues.

\subsection{PsyCap Enables Accurate Perception of Pillars}

We contend that the member's possession of a PsyCap resource enables an accurate perception of the respective Pillar Accuracy of perception is considered to occur when the member gathers information objectively without bias interfering. Decisions and behaviours triggered by that perception are socially appropriate, based upon evolutionary cognitive adaptations [95]. When any member behaves inappropriately or unpredictably, we hypothesise that colleagues will typically disengage.

1 There is only anecdotal and/or indirect evidence of recent welfare policies reducing Indigenous wellbeing because the Australian government repeatedly failed to gather baseline data before implementing its programs [89]. 
Subsequent reduction of net collaborative effort will lead to a weakening of collaboration and a subsequent reduction in each member's BPN [74]. Conversely, comfort and familiarity with a member's behaviour encourages colleagues to remain in collaboration [96] and hence increases collective likelihood of success [50].

In addition to immediate colleague predictability, accurate Pillar perceptions also may aid longer term predictability. This contention is based upon the mentally healthy member expecting their colleagues to operate upon the premise of selfish engagement, which only allows for predictable engagement of all members when Pillars are perceived similarly. For example, selfish engagement may become unpredictable if some members have an inaccurate perception of agency, for instance if their suggestions are secretly being ridiculed. Whereas selfish engagement would expect these members to respond to ridicule by gradually disengaging from the group, by remaining engaged under false perceptions of agency, the group dynamics may become dangerously unpredictable. Eventual realisation of the true state of collaboration may cause extreme emotion that may cause permanent relationship breakdown or even violence. Hence, it is postulated that a colleague with inaccurate perceptions, due to his or her immediate and longer-term unpredictability, will be instinctively avoided by members with accurate Pillar perceptions [97].

We next examine mechanisms that translate PsyCaps to BPN via collaboration. In doing so, we consider that members' possession of PsyCaps allows their accurate Pillar perceptions. While any particular collaboration may fail for unavoidable reasons and thereby reduce members' realisation of BPN, we postulate that members possessing strong PsyCaps have the greatest likelihood of establishing a viable collaboration. By contrast, those members with weak PsyCaps and thereby inaccurate Pillars are more likely to appear unpredictable to members they interact with, and in the longer term, to the group in general.

\section{Translation from PsyCap to BPN via Collaboration}

Five translations from PsyCap to Pillar to BPN are now considered (Table 3). Since prospects and respect were found to not satisfy a $\mathrm{BPN}$, we explored literature for outcomes of collaboration that are similar to a BPN, while not entirely consistent with SDT. Note that for the involved Pillar, we have considered the provider's and receiver's perspective independently.

Table 3. Translation of PsyCap resources via PILAR into BPN and other outcomes.

\begin{tabular}{|c|c|c|}
\hline $\begin{array}{l}\text { PsyCap Resource Influencing Decision } \\
\text { to Collaborate }\end{array}$ & $\begin{array}{l}\text { Member's Pillar Perception of } \\
\text { the Collaboration }\end{array}$ & $\begin{array}{l}\text { Decision-Making Based on Pillar } \\
\text { Satisfies a BPN or Another Outcome }\end{array}$ \\
\hline $\begin{array}{l}\text { Ability to recover from failure allows the } \\
\text { member to clearly evaluate the likelihood of } \\
\text { collaboration success (PsyCap-resilience). }\end{array}$ & $\begin{array}{l}\text { Member's perception of the likelihood that } \\
\text { the collaboration will succeed (prospects) }\end{array}$ & $\begin{array}{l}\text { Other: opportunity to alert others or leave. } \\
\text { Reduced stress. }\end{array}$ \\
\hline $\begin{array}{l}\text { Ability to change direction where necessary } \\
\text { (PsyCap-optimism) }\end{array}$ & $\begin{array}{l}\text { Member's perception of whether offers of, } \\
\text { or requests for, assistance will be accepted } \\
\text { (involved: Receiver) }\end{array}$ & $\begin{array}{l}\text { Need: damage to mastery and challenge } \\
\text { (BPN-competence) }\end{array}$ \\
\hline $\begin{array}{l}\text { Trusting that others are generally } \\
\text { well-disposed and likely to cooperate } \\
\text { sincerely (PsyCap-optimism) }\end{array}$ & $\begin{array}{l}\text { Member's perception of whether offers of, } \\
\text { or requests for, assistance will be accepted } \\
\text { (involved: Provider) }\end{array}$ & $\begin{array}{l}\text { Need: mastery and challenge } \\
\text { (BPN-competence) }\end{array}$ \\
\hline $\begin{array}{l}\text { Ability to regulate ones' own emotions, } \\
\text { and perceive others (PsyCap-EI) }\end{array}$ & $\begin{array}{l}\text { Member's perception of whether colleagues } \\
\text { like them (liked) }\end{array}$ & $\begin{array}{l}\text { Need: caring relationships and sincere } \\
\text { connection with others (BPN-relatedness) }\end{array}$ \\
\hline $\begin{array}{l}\text { Ability to start pursuing a goal } \\
\text { (PsyCap-hope) }\end{array}$ & $\begin{array}{l}\text { Member's perception of whether they can } \\
\text { suggest changes to the group (agency) }\end{array}$ & $\begin{array}{l}\text { Need: for personal choice and volition in } \\
\text { decision making met by having ideas } \\
\text { listened to (BPN-autonomy) }\end{array}$ \\
\hline $\begin{array}{l}\text { The member is confident in their } \\
\text { effectiveness (PsyCap-self-efficacy) }\end{array}$ & $\begin{array}{l}\text { Member's perception of whether each } \\
\text { colleague is competent and trustworthy } \\
\text { (respect). Accumulates to collective-efficacy. }\end{array}$ & Other: motivation and task performance \\
\hline
\end{tabular}

Source: developed from the literature for this research. 


\subsection{PsyCap-PsyCap-resilience $\rightarrow$ Prospects $\rightarrow$ Reduced Stress}

Threats to collaboration success will ideally be recognised and responded to early, otherwise they may become exacerbated [98]. It is therefore beneficial for all collaboration members to independently contemplate their group's prospects, given that each member presumably has access to different information [99].

At early and later stages of collaboration, those with less PsyCap-resilience tend to take an overly rosy or bleak view of prospects, respectively [100]. Since little has been invested, leaving early limits the member's potential loss [101], but once firmly enmeshed in a mature collaboration, aversion to potential loss discourages acknowledgement of information, suggesting ensuing failure [102].

\subsection{PsyCap-PsyCap-optimism $\rightarrow$ Involved (Receiver) $\rightarrow$ BPN-BPN-competence}

Asking for help requires PsyCap-optimism from both the expectancy and attribution perspectives. Regarding expectancy, optimism that good things happen is required given that there are numerous reasons a provider might deny a request for assistance, including opportunity cost, failure and subsequent loss of face, a receiver's lack of gratitude, and diminished advantage of specialised knowledge [103].

Once assistance has been received, the receiver is unlikely to satisfy BPN-competence, since being helped implies the member was not capable of completing this specific task. However, failed cooperation, for instance due to low PsyCap-hope and ensuing lack of adaptation, will also not satisfy BPN-competence. On the other hand, if the receiver's desire not to be involved with the potential provider leads to a solo effort, in the case of failure, it may satisfy BPN-competence in terms of challenge, and in the case of success, satisfy mastery. Note, this is the single instance of a Pillar's inverse causal effect upon a BPN.

\subsection{PsyCap-PsyCap-optimism $\rightarrow$ Involved (Provider) $\rightarrow$ BPN-BPN-competence}

The member who provides help does so in the expectation it will be a constructive exercise, which requires PsyCap-optimism that from both the attribution and expectancy perspective. The attribution perspective is that a positive outcome will eventuate from providing help, as opposed to for instance the offer being rebuffed. The expectancy perspective is that hard work will be rewarded, which promotes assistance because offering help usually requires time and effort.

During the provision of difficult assistance, the provider's need for challenge is satisfied, and if completed successfully, mastery. By contrast, an easy task provides neither challenge nor mastery, while carries less risk of failure. As a result, it is conjectured that providers with less PsyCap-optimism will only assist if requests are easily meet (minimal risk of failure) or are sufficiently interesting to satisfy BPN-competence (with this reward balancing increased risk of failure).

\subsection{PsyCap-EI $\rightarrow$ Liked $\rightarrow$ BPN-Relatedness}

In general, a member with high PsyCap-EI can calibrate their words and body language to achieve higher relatedness or weaker if the relationship is undesirable [104]. High PsyCap-EI allows the member to select people to form relationships with (through networking), whereas members with low PsyCap-EI will tend to accept relationships that are proximate (such as work colleagues) or historical (such as school friends) [105]. Members with low PsyCap-EI may misinterpret their companion's emotional state, making an attempt to achieve connection to be perceived as insincerity [106], which may degrade relationships [107]. With less capacity to optimise relationships, their risk-minimising option is civility and politeness [108].

A member with low PsyCap-EI may also be unaware they are disliked, which reduces their need to monitor the liked perception, while still allowing satisfaction of BPN-relatedness at a moderate level. As a result, only high PsyCap-EI members need be sensitive to the liked perception, since they can 
undertake deliberate repair of relationships [109]. Due to this, and the ability to connect with socially desirable conspecifics, high PsyCap-EI members will experience more intense BPN-relatedness [110].

\subsection{PsyCap-PsyCap-hope $\rightarrow$ Agency $\rightarrow$ BPN-BPN-autonomy}

The member who suggests a change to the group does so in the belief that the change is feasible. On the other hand, the member who feels a change is not feasible will not suggest it. Luthans et al. [47] expressed this rationalisation from the manager's perspective:

[Hopeful managers] accept and respect their followers as individuals, supporting their self-set goals and rewarding their creative pathways, even if these are non-traditional and unusual. Hopeful managers are mentors, coaches, and developers of their associates.

On the other hand, Luthans et al. [47] considers the people with less hope will avoid challenging the status quo:

Hopeful employees tend to be creative and resourceful, even with tight budgets, but they may also portray an impression of chaos and disorganization as they pursue non-traditional, out-of-the-box pathways. In other words, on the surface, high-hopers may appear to be nonconforming troublemakers or risk-takers. Many times, however, we refer to those with such characteristics as "successful entrepreneurs". On the other side of the coin, employees who lack hope may come off as conforming to organizational rules and being obedient to their managers. Low-hopers may be perceived by managers and co-workers as cooperative, "good soldiers".

At a societal level, this rationale explains the opposing views of social progressives and conservatives [111]. Progressives support social "engineering" because they believe that people will not abuse social freedoms [112]. Conservatives respond with suspicion based upon an assumption that people are not trustworthy, and given the opportunity, would abuse social freedoms [113]. Extending this metaphor, in perceiving change as achievable, members in possession of PsyCap-hope are reminiscent of progressives. Those lacking PsyCap-hope perceive the status quo as fragile and any change, however well-intentioned, as ultimately futile [114].

Demonstrating agency by suggesting change allows satisfaction of BPN-autonomy, since the member has exercised their choice [47]. On the other hand, never suggesting change leads to the member's frustration in their limited capacity to exert influence, since, by default, existing methods and traditions continue being used. This may explain why conservative leaders tend to be dictatorial, since their lack of PsyCap-optimism only allows satisfaction of BPN-autonomy through denying it to others, such as through enforcement of inequitable rules [115]. This logic can be reversed and extended to the group, where any colleague's suggestion for change is considered a ploy to gain them power, which the low PsyCap-optimism member will resist [116].

\subsection{PsyCap-PsyCap-self-efficacy $\rightarrow$ Respect $\rightarrow$ Motivation}

Awareness of the colleague's competence and trustworthiness enables a more accurate assessment of task achievement likelihood [117]. Respected colleagues require less monitoring, allowing the member to focus on their own task [118]. In addition, efficacious members tend to have greater goal commitment, meaning less propensity for social loafing [119]. On the other hand, poor respect will require monitoring of colleagues, since the member feels their colleagues are not sufficiently competent or trustworthy to complete their tasks [120].

Collaborating members that can accurately make decisions upon PILAR perceptions will appear predictable to colleagues, which is conducive to their engagement, and thereby collaboration viability [50]. Thus, mentally well members become accustomed to a higher satisfaction of BPN, based upon perceiving Pillars accurately, and therefore learn to seek and maintain collaborations. To continue satisfying their BPN, we contend that mentally well collaborators will monitor their group 
and respond appropriately and proactively to any deficiencies in prospects, involved, respect, agency, and liked.

\section{Discussion}

We have postulated that lower wellbeing reduces individual psychological capital (PsyCap) that enables reliable collaboration with others. In a reinforcing feedback loop, ensuing failure to achieve basic psychological needs (BPN) further reduces wellbeing. Innovation generates national wealth through businesses' capacity to adapt, which relies upon a workforce that can collaborate effectively. However, for those unable to find permanent, well-remunerated employment, damage to wellbeing may counteract the gains of national wealth. Through comprehending collaboration via a model such as PILAR, proactive policies may be developed that directly enhance population wellbeing. As a result, wealth-generating, innovative, open-access economies may achieve outcomes such as improved wellbeing and living standards of precarious workers, reducing ensuing wealth inequality and intergenerational disadvantage [121].

Rather than directly institute a UPI that measures collaboration participation, a more graduated, less expensive, and therefore less contentious approach may be to first build the government's capacity to measure participation via each welfare recipient's collaboration involvement [28]. Conceptually, this requires two levels of confirmation-that a collaboration is legitimate and viable, rather than illegal, dysfunctional, or hollow, and that a member's participation within that collaboration is productive. Regarding the former, a five-item survey instrument (Pillar-PP) based upon PILAR asks each member to rate how each of their peer's perceives the collaboration [122]. This avoids scoring peers for their relative contribution, which may be prone to inter-rater biases resulting from personal relationships [123,124]. Should Pillar-PP data indicate that all members are perceiving a viable collaboration, then no further action is required. However, if the responses indicate uneven perceptions, a further round of more detailed surveys, this time including peer assessment, may establish whether the collaboration is hollow and not achieving outcomes that members value or that certain members are not productively engaged. If the former, the collaboration might be deregistered, and if the latter, certain members might require assistance with collaborations skills [125] or else be asked to leave by the majority.

\section{Collaboration Vouchers}

Given that the less wealthy may lack the financial means to participate in certain collaborations, the government will ideally provide a subsidy that, in addition, incentivises completion of a collaboration viability survey [126]. A novel policy designed by the lead author to provide subsidies is Collaboration Vouchers ( $\mathrm{CoVr}$ ), which are annual grants given to each citizen, able to be spent on the membership fees of any registered collaboration (for detail of a CoVr policy, see Appendix F of [127]). For example, joining groups will broaden the personal network of long-term unemployed, who may then may find work through identifying opportunities and gaining personal recommendations.

To avoid the misspending of taxpayer's money, there would have to be a requirement for a collaboration to have a higher goal than simply disbursing membership fees back to the members. Therefore, to become registered to receive vouchers, a collaboration first informs the government of its intended purpose and the identity of its leadership and executive. Such an approach has been adopted by the recently instituted Australian Charities and Not-for-profits Commission, who require reporting of the use of private and public donations so that organisations may continue to receive favourable taxation status [128].

$\mathrm{CoVr}$ might generally increase insight into charitable service quality, providers of which are otherwise often funded through government grants. Charities often have difficulty measuring their impact, but if their clients became part of the funding base, customer feedback would be made intrinsic [128]. Specifically, a high quality of service would be indicated by a growing number of 
the charities' clients retaining their memberships. In addition, using a matched funding arrangement, this data could be leveraged to attract further philanthropic donations or public grants, [129].

$\mathrm{CoVr}$ may replace other existing public grants or taxation treatments, such as innovation seed funding, tax treatment of union memberships, and public funding of media organisations. Registered collaborations might constitute a launch pad for entrepreneurial ideas, with vouchers used by potential early adopter customers, such as currently occurs within crowd funding platforms. Unions may become registered collaborations, able to receive vouchers, and hence represent not only salaried employees but also the precariat and unemployed. The media, who are losing advertising revenue to Google and Facebook, may also become registered collaborations, able to accept vouchers in return for subscriptions $[130,131]$. This option is however problematic as media consumption is not collaborative, nevertheless media organisations might participate by sponsoring local groups reporting on and analysing issues, with resulting articles considered for publication.

While the CoVr policy is admittedly utopian and will initially impose an additional burden on public budgets to fund vouchers, as well as associated government oversight and IT systems, the idea is nevertheless clearly articulated, which is the first step of successful implementation [132]. Voucher programs have recently been implemented, such as the Australian National Disability Insurance Service (NDIS) [133] and Active Kids vouchers [134] in addition to, for over a decade of operation, an Icelandic voucher system promoting adolescent recreation that has contributed to reducing harmful behaviours [135]. In congruence with Iceland's multipronged approach that includes wealth redistributive policies, to ensure people have sufficient recreational time to participate and are not otherwise living in poverty, $\mathrm{CoVr}$ would work in tandem with welfare provision and industrial regulations, such as a minimum wage [13]. Similarly, CoVr would complement programs such as the NDIS and child-specific vouchers such as Active Kids by promoting collaborative activities for a person rendered sufficiently able and of legally competent age to participate.

In terms of political support, a CoVr scheme may satisfy the capitalist ideology because it relies upon market forces in terms of the "spending" power of the "consumer" to weed out ineffectual collaboration and may therefore find public support in individualist nations such as the United States. Conversely, since members of collectivist nations defer to local leaders, these leaders might support $\mathrm{CoVr}$ as a method of financing cultural institutions. We postulate that once CoVr are established, over time progressively larger vouchers will allow greater scale of activities with potential to meet the psychological, physical and even financial needs of members, perhaps eventually obviating the need for a UPI. This may occur at a substantially lower level of UPI funding due to greater utilisation of collective effort for collective benefit, rather than public funds for delivery of goods and services being partly converted into profit. Another distinct advantage of $\mathrm{CoVr}$ may be in exposing the population to local leadership rather than the influence of mass marketing and populist media.

\section{Conclusions}

Amongst the contrasting right and left perspectives of free-market capitalism and wealth-redistributive socialism, this article has sought to develop an economically robust policy response to increasing wealth inequality and precarious employment. Taking the desired twin outcomes of societal wellbeing and innovation, we have incorporated theory from positive psychology, as well as the novel PILAR model of collaboration, to postulate the interaction of wellbeing, positive psychology, and collaboration. This cyclical understanding allows a contention that policy designed to improve collaboration will thereupon improve collaborating member's wellbeing. Additionally, since a positive feedback loop is contended, such a policy may deliver a long-term effect, and hence, represent a cost-effective policy mechanism.

We have proposed a novel paradigm that may unify the achievement of societal wellbeing and economic success, for instance though the CoVr policy. The paradigm is consistent with economic wealth resulting from collaboration, via PILAR, being necessary for the process of innovation, from idea conceptualisation to team effectiveness. The paradigm is also consistent with a welfare system, since collaboration is integral to the postulated wellbeing cycle. Further research is necessary for the 
validation of both foundations of the paradigm, and furthermore to test the effectiveness of CoVr in a population relative to policies with a similar intent, such as a UBI.

The overall paucity of research regarding voucher policies for social gain suggests a significant gap in the literature. This gap may exist because such a policy fits neither of the narratives that drive the majority of sociological and economic policy literatures. Resolving these competing narratives may lead to policies, such as $\mathrm{CoVr}$, that allow for significant advances to economic productivity as well as social wellbeing, rather than there being a tradeoff assumed to be unavoidable.

Author Contributions: Benjamin Heslop conceived of the research and wrote the article. Other authors provided advice on theory development and manuscript preparation. J.P. created Figure 1.

Conflicts of Interest: The authors declare no conflicts of interest.

\section{References}

1. Černe, M.; Jaklič, M.; Škerlavaj, M. Decoupling management and technological innovations: Resolving the individualism-collectivism controversy. J. Int. Manag. 2013, 19, 103-117. [CrossRef]

2. Aloisi, A. Commoditized workers: Case study research on labor law issues arising from a set of "on-demand/gig economy platforms". Comp. Labor. Law Policy J. 2016, 37, 653-690.

3. North, D.C.; Wallis, J.J.; Weingast, B.R. Violence and the Rise of Open-Access Orders. J. Democr. 2009, 20, 55-68. [CrossRef]

4. Helliwell, J.; Layard, R.; Sachs, J. World Happiness Report 2017; Sustainable Development Solutions Network: New York, NY, USA, 2017.

5. Carlisle, S.; Henderson, G.; Hanlon, P.W. 'Wellbeing': A collateral casualty of modernity? Soc. Sci. Med. 2009, 69, 1556-1560. [CrossRef] [PubMed]

6. MacCoy, D.J. Appreciative Inquiry and Evaluation-Getting to What Works. Can. J. Program Eval. 2014, 29, 104-127. [CrossRef]

7. Salazar, M.R.; Lant, T.K.; Fiore, S.M.; Salas, E. Facilitating Innovation in Diverse Science Teams through Integrative Capacity. Small Group Res. 2012, 43, 527-558. [CrossRef]

8. Tomasello, M. The ultra-social animal. Eur. J. Soc. Psychol. 2014, 44, 187-194. [CrossRef] [PubMed]

9. Glaeser, E.L.; Gottlieb, J.D. The Wealth of Cities: Agglomeration Economies and Spatial Equilibrium in the United States. J. Econ. Lit. 2009, 47, 983-1028. [CrossRef]

10. Standing, G. The Precariat; Bloomsbury Academic: London, UK, 2011.

11. Barr, B.; Kinderman, P.; Whitehead, M. Trends in mental health inequalities in England during a period of recession, austerity and welfare reform 2004 to 2013. Soc. Sci. Med. 2015, 147, 324-331. [CrossRef] [PubMed]

12. Chesbrough, H. Open Innovation: The New Imperative for Creating and Profiting from Technology; Harvard Business School Press: Boston, MA, USA, 2006.

13. Campbell, P.; Kelly, P.; Harrison, L. Transitional Labour Market Programs: Challenges and Opportunities; Alfred Deakin Research Institute, Deakin University: Geelong, Australia, 2011.

14. Doody, S.; Chen, V.T.; Goldstein, J. Varieties of Entrepreneurial Capitalism: The Culture of Entrepreneurship and Structural Inequalities of Work and Business Creation. Sociol. Compass 2016, 10, 858-876. [CrossRef]

15. Friedman, G. Workers without employers: Shadow corporations and the rise of the gig economy. Rev. Keynes. Econ. 2014, 2, 171-188. [CrossRef]

16. Amoore, L. Risk, reward and discipline at work. Econ. Soc. 2004, 33, 174-196. [CrossRef]

17. Bogenhold, B.D.; Klinglmair, A. Micro-Entrepreneurship: Tendency towards Precarious Work? Empirical Findings for Austria. Athens J. Bus. Econ. 2015, 1, 107-122.

18. Kinderman, P.; Tai, S.; Pontin, E.; Schwannauer, M.; Jarman, I.; Lisboa, P. Causal and mediating factors for anxiety, depression and well-being. Br. J. Psychiatry 2015, 206, 456-460. [CrossRef] [PubMed]

19. Bowles, S.; Gintis, H. Social capital and community governance. Econ. J. 2002, 112, F419-F436. [CrossRef]

20. Schmid, G. Transitional labour markets: Experiences from Europe and Germany. Aust. Bull. Labour 2006, 32, 114-139.

21. Andersen, T.M. The Danish Flexicurity Labour Market During the Great Recession. De Economist 2015, 163, 473-490. [CrossRef] 
22. Saint-Paul, G. Employment protection, international specialization, and innovation. Eur. Econ. Rev. 2002, 46, 375-395. [CrossRef]

23. Lommerud, K.E.; Straume, O.R. Employment Protection versus Flexicurity: On Technology Adoption in Unionised Firms; CESifo Working Paper Series 2472; CESifo Group Munich: Munich, Germany, 2008. Available online: https: / / doi.org/10.1016/J.JPUBECO.2010.06.006 (accessed on 27 February 2018).

24. Boyer, R. Employment and Decent Work in the Era of Flexicurity; PSE Working Papers $\mathrm{n}^{\circ} 2006-21 ; 2006$. Available online: http:/ / hal.archives-ouvertes.fr/halshs-00590452/ (accessed on 27 February 2018).

25. Thepovertyline.net. The Poverty Line. Available online: http://www.thepovertyline.net/france/ (accessed on 23 February 2018).

26. Zamora, D. The Case against a Basic Income. Available online: https:/ /www.jacobinmag.com/2017/12/ universal-basic-income-inequality-work (accessed on 20 January 2018).

27. Greenstein, B. Universal Basic Income May Sound Attractive But, If It Occurred, Would Likelier Increase Poverty Than Reduce It. Available online: https: / / www.huffingtonpost.com/bob-greenstein/ commentaryuniversal-basi_b_10229506.html (accessed on 20 May 2018).

28. de Wispelaere, J.; Noguera, J.A. Basic Income Guarantee and Politics, 1st ed.; Caputo, R.K., Ed.; Palgrave Macmillan: New York, NY, USA, 2012; p. 322.

29. Fletcher, G.J.O.; Clark, M.S. Interpersonal Processes; Blackwell Publishing: Malden, MA, USA, 2003.

30. Twenge, J.M.; Martin, G.N.; Campbell, W.K. Decreases in Psychological Well-Being among American Adolescents after 2012 and Links to Screen Time During the Rise of Smartphone Technology. Emotion 2018. [CrossRef] [PubMed]

31. Salas, E.; Shuffler, M.L.; Thayer, A.L.; Bedwell, W.L.; Lazzara, E.H. Understanding and Improving Teamwork in Organizations: A Scientifically Based Practical Guide. Hum. Resour. Manag. 2015, 54, 599-622. [CrossRef]

32. Heslop, B.; Stojanovski, E.; Paul, J.; Bailey, K. PILAR: A Model of Collaboration to Encapsulate Social Psychology. Rev. Gen. Psychol. 2018. [CrossRef]

33. Heslop, B.; Paul, J.; Drew, A.; Bailey, K.; Stojanovski, E. Organisational Psychology and Appreciative Inquiry: Unifying the Empirical and the Mystical. AI Pract. 2018, 20, 69-90. [CrossRef]

34. Costa, P.L.; Passos, A.M.; Bakker, A.B. Team work engagement: A model of emergence. J. Occup. Organ. Psychol. 2014, 87, 414-436. [CrossRef]

35. Quinn, R.W.; Dutton, J.E. Coordination as Energy-in-Conversation. Acad. Manag. Rev. 2005, 30, 36-57. [CrossRef]

36. Klein, J.K.; Lim, B.-C.; Saltz, J.L.; Mayer, D.M. How Do They Get There? An Examination of the Antecedents of Centrality in Team Networks. Acad. Manag. J. 2004, 47, 952-963.

37. Meeussen, L.; Delvaux, E.; Phalet, K. Becoming a group: Value convergence and emergent work group identities. Br. J. Soc. Psychol. 2014, 53, 235-248. [CrossRef] [PubMed]

38. Spânu, F.; Băban, A.; Bria, M.; Lucăcel, R.; Florian, I.Ş.; Rus, L. Error Communication and Analysis in Hospitals: The Role of Leadership and Interpersonal Climate. Procedia Soc. Behav. Sci. 2013, 84, 949-953. [CrossRef]

39. Swann, W.B.; Griffin, J.J.; Predmore, S.C.; Gaines, B. The cognitive-affective crossfire: When self-consistency confronts self-enhancement. J. Pers. Soc. Psychol. 1987, 52, 881-889. [CrossRef] [PubMed]

40. Ibrahim, M.; Ribbers, P.M. The impacts of competence-trust and openness-trust on interorganizational systems. Eur. J. Inf. Syst. 2009, 18, 223-234. [CrossRef]

41. Ko, D. Consultant competence trust doesn't pay off, but benevolent trust does! Managing knowledge with care. J. Knowl. Manag. 2010, 14, 202-213. [CrossRef]

42. Bushe, G.R.; Marshak, R.J. Revisioning Organization Development: Diagnostic and Dialogic Premises and Patterns of Practice. J. Appl. Behav. Sci. 2009, 45, 348-368. [CrossRef]

43. Makadok, R. Both Market and Hierarchy: An Incentive-Systems Theory of Hybrid Governance Forms Both Market and Hierarchy: An Incentive-Systems Theory of Hybrid Governance Forms. Acad. Manag. Rev. 2009, 34, 297-319. [CrossRef]

44. Rizzo, J.R.; House, R.J.; Lirtzman, S. Role Conflict and Ambiguity in Complex Organizations. Adm. Sci. Q. 1970, 15, 150-163. [CrossRef]

45. Klotz, A.C.; Hmieleski, K.M.; Bradley, B.H.; Busenitz, L.W. New Venture Teams: A Review of the Literature and Roadmap for Future Research. J. Manag. 2013, 40, 226-255. [CrossRef] 
46. Jin, L.; Madison, K.; Kraiczy, N.D.; Kellermanns, F.W.; Crook, T.R.; Xi, J. Entrepreneurial Team Composition Characteristics and New Venture Performance: A Meta-Analysis. Entrep. Theory Pract. 2017, 41, 743-771. [CrossRef]

47. Luthans, F.; Youssef, C.; Avolio, B. Psychological Capital: Developing the Human Competitive Edge; Oxford University Press: New York, NY, USA, 2007.

48. Rothmann, S.; Diedericks, E.; Swart, J.P. Manager relations, psychological need satisfaction and intention to leave in the agricultural sector. SA J. Ind. Psychol. 2013, 39, a1129. [CrossRef]

49. Robinson, P.; Oades, L.; Caputi, P. Conceptualising and Measuring Mental Fitness: A Delphi Study. Int. J. Wellbeing 2015, 5, 53-73. [CrossRef]

50. Verleysen, B.; Lambrechts, F.; van Acker, F. Building Psychological Capital with Appreciative Inquiry. J. Appl. Behav. Sci. 2015, 51, 10-35. [CrossRef]

51. Greguras, G.J.; Diefendorff, J.M. Different fits satisfy different needs: Linking person-environment fit to employee commitment and performance using self-determination theory. J. Appl. Psychol. 2009, 94, 465-477. [CrossRef] [PubMed]

52. Sheldon, K.M.; Kasser, T. Pursuing Personal Goals: Skills Enable Progress, but Not all Progress is Beneficial. Pers. Soc. Psychol. Bull. 1998, 24, 1319-1331. [CrossRef]

53. Ryan, R.M.; Deci, E.L. Self-Determination Theory and the Facilitation of Intrinsic Motivation, Social Development, and Well-Being. Am. Psychol. 2000, 55, 68-78. [CrossRef] [PubMed]

54. Luthans, F. The need for and meaning of positive organizational behavior. J. Organ. Behav. 2002, 23, 695-706. [CrossRef]

55. Rego, A.; Sousa, F.; Cunha, M.P.; Correia, A.; Saur-Amaral, I. Leader Self-Reported Emotional Intelligence and Perceived Employee Creativity: An Exploratory Study. Creat. Innov. Manag. 2007, 16, 250-264. [CrossRef]

56. Taylor, R.D.; Oberle, E.; Durlak, J.A.; Weissberg, R.P. Promoting Positive Youth Development through School-Based Social and Emotional Learning Interventions: A Meta-Analysis of Follow-Up Effects. Child Dev. 2017, 88, 1156-1171. [CrossRef] [PubMed]

57. Pradhan, R.K.; Jena, L.K.; Bhattacharya, P.; Nisar, T. Impact of psychological capital on organizational citizenship behavior: Moderating role of emotional intelligence. Cogent Bus. Manag. 2016, 3, 1194174. [CrossRef]

58. Morrison, E. Role definitions and organizational citizenship behavior: The importance of the employee's perspective. Acad. Manag. J. 1994, 37, 1543-1567.

59. Snyder, C.R. Hope Theory: Rainbows in the Mind. Psychol. Inq. 2002, 13, 249-275. [CrossRef]

60. Seligman, M.E.P. What is the 'Good Life'? Monit. Am. Psychol. Assoc. 1998, 29, 1-2. Available online: http:/ /209-197-41-56.unassigned.ntelos.net/images/stories/library/Stennett_Psychology_Articles/ What_Is_the_Good_Life.pdf (accessed on 1 October 2017).

61. Scheier, M.; Carver, C. Optimism, coping, and health: Assessment and implications of generalized outcome expectancies. Heal. Psychol. 1985, 4, 219-247. [CrossRef]

62. Bandura, A. Handbook of Principles of Organization Behavior; Locke, E.A., Ed.; Wiley: New York, NY, USA, 2009; pp. 179-200.

63. Bandura, A. Self-efficacy. Encycl. Hum. Behav. 1994, 4, 1-65.

64. Tuckey, M. The influence of motives and goal orientation on feedback seeking. J. Occup. 2002, 75, $195-216$. [CrossRef]

65. VandeWalle, D.; Cummings, L. A test of the influence of goal orientation on the feedback-seeking process. J. Appl. Psychol. 1997, 82, 390-400. [CrossRef] [PubMed]

66. Luthans, F.; Avey, J.B.; Avolio, B.J.; Peterson, S.J. The Development and Resulting Performance Impact of Positive Psychological Capital. Hum. Resour. Dev. Q. 2010, 21, 41-67. [CrossRef]

67. Luthans, F.; Vogelgesang, G.R.; Lester, P.B. Developing the Psychological Capital of Resiliency. Hum. Resour. Dev. Rev. 2006, 5, 25-44. [CrossRef]

68. Cole, K. Wellbeing, psychological capital, and unemployment: An integrated theory. In Proceedings of the Joint Annual Conference of the International Association for Research in Economic Psychology (IAREP) and the Society for the Advancement of Behavioural Economics (SABE), Paris, France, 5-8 July 2006; pp. 1-16.

69. Li, B.; Ma, H.; Guo, Y.; Xu, F.; Yu, F.; Zhou, Z. Positive psychological capital: A new approach to social support and subjective well-being. Soc. Behav. Pers. Int. J. 2014, 42, 135-144. [CrossRef]

70. Vansteenkiste, M.; Ryan, R.M. On psychological growth and vulnerability: Basic psychological need satisfaction and need frustration as a unifying principle. J. Psychother. Integr. 2013, 23, 263-280. [CrossRef] 
71. Avey, J.B. The Left Side of Psychological Capital: New Evidence on the Antecedents of PsyCap. J. Leadersh. Organ. Stud. 2014, 21, 141-149. [CrossRef]

72. Hone, L.C.; Jarden, A.; Schofield, G.; Duncan, S. Measuring flourishing: The impact of operational definitions on the prevalence of high levels of wellbeing. Int. J. Wellbeing 2014, 4, 62-90. [CrossRef]

73. Breevaart, K.; Bakker, A.B.; Demerouti, E.; Hetland, J. The Measurement of State Work Engagement: A multilevel factor analytic study. Eur. J. Psychol. Assess. 2012, 28, 305-312. [CrossRef]

74. Heslop, B.; Paul, J.; Stojanovski, E.; Bailey, K.; Drew, A. Selfish engagement: Consilience of evolutionary theories? Hum. Nat. 2018. [CrossRef]

75. Gintis, H. Strong reciprocity and human sociality. J. Theor. Biol. 2000, 206, 169-179. [CrossRef] [PubMed]

76. Keyes, C.L.M.; Simoes, E.J. To Flourish or Not: Positive Mental Health and All-Cause Mortality. Am. J. Public Health 2012, 102, 2164-2172. [CrossRef] [PubMed]

77. Huppert, F.A.; So, T.T.C. Flourishing Across Europe: Application of a New Conceptual Framework for Defining Well-Being. Soc. Indic. Res. 2013, 110, 837-861. [CrossRef] [PubMed]

78. Diener, E.; Wirtz, D.; Tov, W.; Kim-Prieto, C.; Choi, D.W.; Oishi, S.; Biswas-Diener, R. New well-being measures: Short scales to assess flourishing and positive and negative feelings. Soc. Indic. Res. 2010, 97, 143-156. [CrossRef]

79. Seligman, M.E.P. Flourish: A Visionary New a Understanding of Happiness and Well-Being; Free Press: New York, NY, USA, 2011.

80. Murphy, L.K.; Bettis, A.H.; Gruhn, M.A.; Gerhardt, C.A.; Vannatta, K.; Compas, B.E. Resilience in Adolescents with Cancer: Association of Coping with Positive and Negative Affect. J. Dev. Behav. Pediatr. 2017, 38, 646-653. [CrossRef] [PubMed]

81. Zautra, A.J.; Johnson, L.M.; Davis, M.C. Positive Affect as a Source of Resilience for Women in Chronic Pain. J. Consult. Clin. Psychol. 2005, 73, 212-220. [CrossRef] [PubMed]

82. Moskowitz, J.T.; Carrico, A.W.; Duncan, L.G.; Cohn, M.A.; Cheung, E.O.; Batchelder, A.; Acree, M.; Folkman, S. Randomized Controlled Trial of a Positive Affect Intervention for People Newly Diagnosed With HIV. J. Consult. Clin. Psychol. 2017, 85, 409-423. [CrossRef] [PubMed]

83. Lord, J.H.; Rumburg, T.M.; Jaser, S.S. Staying positive: Positive affect as a predictor of resilience in adolescents with type 1 diabetes. J. Pediatr. Psychol. 2014, 40, 968-977. [CrossRef] [PubMed]

84. Zeigler-Hill, V. Discrepancies between implicit and explicit self-esteem: Implications for narcissism and self-esteem instability. J. Pers. 2006, 74, 119-143. [CrossRef] [PubMed]

85. Chen, R.; Hwang, K.K. Nation, face, and identity: An initial investigation of national face in East Asia. Front. Psychol. 2016, 7, 1-11. [CrossRef] [PubMed]

86. Li, X.; Zheng, X. Adult Attachment Orientations and Subjective Well-Being: Emotional Intelligence and Self-Esteem As Moderators. Soc. Behav. Pers. Int. J. 2014, 42, 1257-1265. [CrossRef]

87. Cambron, M.J.; Acitelli, L.K.; Steinberg, L. When friends make you blue: The role of friendship contingent self-esteem in predicting self-esteem and depressive symptoms. Pers. Soc. Psychol. Bull. 2010, 36, 384-397. [CrossRef] [PubMed]

88. Extremera, N.; Quintana-Orts, C.; Mérida-López, S.; Rey, L. Cyberbullying victimization, self-esteem and suicidal ideation in adolescence: Does emotional intelligence play a buffering role? Front. Psychol. 2018, 9 , 367. [CrossRef] [PubMed]

89. Mendes, P.; Waugh, J.; Flynn, C. Income management in Australia: A critical examination of the evidence. Int. J. Soc. Welf. 2014, 23, 362-372. [CrossRef]

90. Cobb-clark, D.A.; Kettlewell, N.; Schurer, S.; Silburn, S. The Effect of Quarantining Welfare on School Attendance in Indigenous Communities; LCC Working Paper Series: 2017-22; Australian National University: Sydney, Australia, 2017.

91. Hafner, R.J.; White, M.P.; Handley, S.J. Spoilt for choice: The role of counterfactual thinking in the excess choice and reversibility paradoxes. J. Exp. Soc. Psychol. 2012, 48, 28-36. [CrossRef]

92. Yugendhar, A.; Ali, S.M. Evaluation of Implementing Holacracy, A Comprehensive Study on Zappos. Int. J. Eng. Manag. Res. 2017, 7, 163-171.

93. Breunig, R.; Hasan, S.; Hunter, B. Financial Stress and Indigenous Australians; IZA-Institute of Labor Economics: Bonn, Germany, 2017.

94. Bielefeld, S. Government mythology on income management, alcohol, addiction and Indigenous communities. Crit. Soc. Policy 2018, 1-22. [CrossRef] 
95. Tooby, J.; Cosmides, L. The past explains the present. Ethol. Sociobiol. 1990, 11, 375-424. [CrossRef]

96. Rock, D.; Cox, C. SCARF in 2012: Updating the social neuroscience of collaborating with others. Neuroleadersh. J. 2012, 4, 1-14.

97. Oakley, D.A.; Halligan, P.W. Chasing the Rainbow: The Non-conscious Nature of Being. Front. Psychol. 2017, 8, 1-16. [CrossRef] [PubMed]

98. LePine, J.A. Adaptation of teams in response to unforeseen change: Effects of goal difficulty and team composition in terms of cognitive ability and goal orientation. J. Appl. Psychol. 2005, 90, 1153-1167. [CrossRef] [PubMed]

99. Luthans, F.; Youssef, C.M. Emerging Positive Organizational Behavior. J. Manag. 2007, 33, 321-349. [CrossRef]

100. Reivich, K.; Shatte, A. The Resilience Factor: 7 Essential Skills for Overcoming Life's Inevitable Obstacles; Broadway Books: New York, NJ, USA, 2002.

101. Graham, A.; Sloan, K. Resilience at Work: Navigating a Dynamic World (The Resilience Project No. 1). Chicago, IL. 2016. Available online: http://www.sloangroupinternational.com/the-resilience-project/ (accessed on 1 October 2017).

102. Kahneman, D. Thinking, Fast and Slow (Allen Lane); Penguin Books Ltd.: London, UK, 2011.

103. Andras, P.; Lazarus, J. The evolution of teamwork, cooperation and risk. In Teamwork Multi-Disciplinary Perspectives; Palgrave Macmillan: London, UK, 2005; pp. 56-77.

104. Côté, S.; DeCelles, K.A.; McCarthy, J.M.; van Kleef, G.A.; Hideg, I. The Jekyll and Hyde of Emotional Intelligence. Psychol. Sci. 2011, 22, 1073-1080. [CrossRef] [PubMed]

105. Emery, C. Uncovering the role of emotional abilities in leadership emergence: A longitudinal analysis of leadership networks. Soc. Netw. 2012, 34, 429-437. [CrossRef]

106. Brown, P.; Levinson, S.C. Politeness: Some Universals in Language Usage, 4th ed.; Cambridge University Press: Cambridge, UK, 1987.

107. Wei, H.-S.; Chen, J.-K. The moderating effect of Machiavellianism on the relationships between bullying, peer acceptance, and school adjustment in adolescents. Sch. Psychol. Int. 2012, 33, 345-363. [CrossRef]

108. Porath, C.L.; Gerbasi, A.; Schorch, S.L. The Effects of Civility on Advice, Leadership, and Performance. J. Appl. Psychol. 2015, 100, 1527-1541. [CrossRef] [PubMed]

109. Schutte, N.; Malouff, J.; Bobik, C.; Coston, T.; Greeson, C.; Jedlicka, C.; Rhodes, E.; Wendorf, G. Emotional Intelligence and Interpersonal Relations. J. Soc. Psychol. 2001, 141, 523-536. [CrossRef] [PubMed]

110. Fang, R.; Landis, B.; Zhang, Z.; Anderson, M.H.; Shaw, J.D.; Kilduff, M. Integrating Personality and Social Networks: A Meta-Analysis of Personality, Network Position, and Work Outcomes in Organizations. Organ. Sci. 2015, 26, 1243-1260. [CrossRef]

111. Kahan, D.M.; Braman, D.; Slovic, P.; Gastil, J.; Cohen, G.L. The second national risk and culture study: Making sense of-and making progress in-the American culture war of fact (No. 154). Public Law Working Papers. 2007. Available online: https:/ / doi.org/10.2139/ssrn.1017189 (accessed on 1 October 2017).

112. Passmore, J.; Peterson, D.B.; Freire, T.; Leonard, H.S.; Lewis, R.; Freedman, A.M. The Wiley-Blackwell Handbook of the Psychology of Leadership of Change, and Organizational Development; Wiley-Blackwell: Hoboken, NJ, USA, 2013.

113. Merton, R.K. Social Theory and Social Structure; The Free Press: New York, NY, USA, 1968.

114. Markovsky, B.; Dilks, L.M.; Koch, P.; McDonough, S.; Triplett, J.; Velasquez, L. Advances in Group Processes, 25th ed.; Hegtvedt, K.A., Clay-Warner, J., Eds.; Emerald Group Publishing Limited: Bingley, UK, 2008; pp. 345-371.

115. Pratto, F.; Sidanius, J.; Levin, S. Social dominance theory and the dynamics of intergroup relations: Taking stock and looking forward. Eur. Rev. Soc. Psychol. 2006, 17, 271-320. [CrossRef]

116. Johnson, D.W.; Johnson, R.T. Cooperative Learning in 21st Century. Anales de Psicología 2014, 30, 841-851. [CrossRef]

117. Fernández-Ballesteros, R.; Díez-Nicolás, J.; Caprara, G.V.; Barbaranelli, C.; Bandura, A. Determinants and Structural Relation of Personal Efficacy to Collective Efficacy. Appl. Psychol. Int. Rev. 2002, 51, 107-125. [CrossRef]

118. Mulvey, P.; Klein, H. The Impact of Perceived Loafing and Collective Efficacy on Group Goal Processes and Group Performance. Organ. Behav. Hum. Decis. Process. 1998, 74, 62-87. [CrossRef] [PubMed]

119. Erez, A.; Judge, T.A. Relationship of core self-evaluations to goal setting, motivation, and performance. J. Appl. Psychol. 2001, 86, 1270-1279. [CrossRef] [PubMed] 
120. Kellett, J.B.; Humphrey, R.H.; Sleeth, R.G. Career development, collective efficacy, and individual task performance. Career Dev. Int. 2009, 14, 534-546. [CrossRef]

121. Cobb-clark, D.A.; Dahmann, S.C.; Salamanca, N.; Zhu, A. Intergenerational Disadvantage: Learning about Equal Opportunity from Social Assistance Receipt (Melbourne Institute Working Paper No. 28/17). Melbourne. 2017. Available online: https:/ / dx.doi.org/10.2139/ssrn.3053620 (accessed on 21 January 2018).

122. Heslop, B.; Stojanovski, E.; Paul, J.; Bailey, K. Are We Collaborating Yet? Employee Assessment of Peer's Perceptions. Int. J. Hum. Resour. Stud. 2017, 7, 175-192. [CrossRef]

123. O'Neill, T.A.; McLarnon, M.J.W.; Carswell, J.J. Variance Components of Job Performance Ratings. Hum. Perform. 2015, 28, 66-91. [CrossRef]

124. Viswesvaran, C.; Schmidt, F.L.; Ones, D.S. Is There a General Factor in Ratings of Job Performance? A Meta-Analytic Framework for Disentangling Substantive and Error Influences. J. Appl. Psychol. 2005, 90, 108-131. [CrossRef] [PubMed]

125. Heslop, B.; Bailey, K.; Stojanovski, E.; Paul, J. Do Self-Interested Learners Avoid Prosocial Learning? Preprints, 2018010050. 2018. Available online: https://www.preprints.org/manuscript/201801.0050/v1 (accessed on 8 January 2018).

126. Ettlinger, N. The production of precariousness and implications for collective action: A reply to Emiliana Armano and Annalisa Murgia. Glob. Discourse 2013, 3, 502-506. [CrossRef]

127. Heslop, B. PILAR: Proposed Systemic Model of Collaboration. University of Newcastle: Newcastle, Australia, 2018.

128. Australian Charities and Not-for-Profits Commission. ACNC Myth-Busts Charity Admin Costs. Available online: https:/ / www.acnc.gov.au/ACNC/Comms/Med_R/MR_177.aspx (accessed on 22 February 2018).

129. Vernon, J.; Essex, S.; Pinder, D.; Curry, K. Collaborative policymaking: Local sustainable projects. Ann. Tour. Res. 2005, 32, 325-345. [CrossRef]

130. Canning, S. Print spiral accelerates as newspapers lose more than $\$ 100 \mathrm{~m}$ in ad revenue reveals SMI. Available online: https:/ / mumbrella.com.au/print-spiral-accelerates-as-newspapers-lose-more-than-100m-in-adrevenue-smi-reveals-459938 (accessed on 22 May 2018).

131. Simons, M. After endless political handwringing over journalism, glimmers of hope emerge. 2018. Available online: https: / www.theguardian.com/media/2018/feb/23/reports-of-journalisms-imminent-demiseare-exaggerated-but-politicians-arent-helping. (accessed on 23 May 2018).

132. van Parijs, P. The universal basic income: Why utopian thinking matters, and how sociologists can contribute to it. Polit. Soc. 2013, 41, 171-182. [CrossRef]

133. Walsh, J.; Johnson, S. Development and Principles of the National Disability Insurance Scheme. Aust. Econ. Rev. 2013, 46, 327-337. [CrossRef]

134. NSW Government Office of Sport, Active Kids. Available online: https://sport.nsw.gov.au/sectordevelopment/ activekids (accessed on 27 March 2018).

135. Young, E. How Iceland Got Teens to Say No to Drugs. The Atlantic, 31 January 2017; pp. 1-15. Available online: https://www.theatlantic.com/health/archive/2017/01/teens-drugs-iceland/513668/ (accessed on 10 May 2018).

(C) 2018 by the authors. Licensee MDPI, Basel, Switzerland. This article is an open access article distributed under the terms and conditions of the Creative Commons Attribution (CC BY) license (http://creativecommons.org/licenses/by/4.0/). 